Beata Roguska

Centrum Badania Opinii Społecznej w Warszawie

Jarosław Zbieranek

Centrum Studiów Wyborczych UMK w Toruniu

Biuro Rzecznika Praw Obywatelskich

\title{
OPINIE POLAKÓW O PROPOZYCJACH ZMIAN W PRAWIE WYBORCZYM
}

\section{Wprowadzenie}

W roku 2011 uchwalony został Kodeks wyborczy. ${ }^{1}$ Oprócz uporządkowania obowiązujących dotychczas przepisów wyborczych, wprowadził on również wiele nowych, ważnych mechanizmów i konstrukcji prawnych. Prace koncepcyjne i legislacyjne nad kolejnymi zmianami są jednak kontynuowane. W dyskusjach eksperckich, debacie publicznej oraz na forum parlamentu rozważanych jest wiele różnorodnych propozycji innowacji w zakresie prawa wyborczego. Część z nich wywołuje dość duże kontrowersje. Ponieważ procesowi zmian prawnych powinna towarzyszyć pogłębiona refleksja obejmująca również badania postaw i opinii wyborców, Centrum Studiów Wyborczych Uniwersytetu Mikołaja Kopernika oraz Centrum Badania Opinii Społecznej postanowiły w kwietniu 2014 roku przeprowadzić wspólne badanie dotyczące tych kwestii. ${ }^{2}$ Uznaliśmy, że zbliżające się wówczas wybory do Parlamentu Europejskiego mogą stanowić pewien punkt odniesienia, a okres przedwyborczy i uwaga, przynajmniej części respondentów, skierowana na sprawy związane z wyborami może im w pewnym przynajmniej stopniu ułatwić formułowanie opinii i ocenę proponowanych zmian w prawie wyborczym.

W badaniu skupiliśmy się na kwestiach będących w ostatnim czasie przedmiotem debaty, takich jak: udział procentowy kandydatów różnych płci na listach wyborczych i potencjalne modyfikacje w tym zakresie; propozycje zmian w konstrukcji tzw. ciszy wyborczej; obniżenie granicy wieku uprawniającego do głosowa-

Ustawa z dnia 5 stycznia 2011 roku - Kodeks wyborczy (Dz.U. z 2011 r. Nr 21, poz. 112, z późn. zm.).

Badanie „Aktualne problemy i wydarzenia” (287) przeprowadzono metodą wywiadów bezpośrednich (face-to-face) wspomaganych komputerowo (CAPI) w dniach 3-9 kwietnia 2014 roku na liczącej 1028 osób reprezentatywnej próbie losowej dorosłych mieszkańców Polski. 
nia; ograniczenie dotyczące spotów wyborczych. W badaniu dość szeroko zostały poruszone kwestie związane $\mathrm{z}$ alternatywnymi procedurami głosowania. Biorąc pod uwagę tematykę tomu - problematyka ta w niniejszym artykule została dodatkowo poszerzona o najnowsze wyniki badań (kwiecień 2015 roku) poświęconych wiedzy Polaków i ich preferencji - wobec funkcjonujących procedur: głosowania korespondencyjnego oraz głosowania przez pełnomocnika. Ponadto kontekstowo zbadane zostały tendencje związane z kanałami komunikacji i źródłami wiedzy o wyborach.

Celem niniejszego artykułu jest więc przede wszystkim dostarczenie, w oparciu o wyniki badań opinii społecznej, informacji o opiniach, ocenach, w pewnym stopniu również wiedzy polskich wyborców na temat wybranych konstrukcji prawa wyborczego. Stanowić może on materiał pomocny w pogłębionych, interdyscyplinarnych analizach poszczególnych mechanizmów prawnych, a także potencjalnie umożliwić może szerszą refleksję ustawodawcy i środowisk politycznych na temat niektórych kierunków reform prawa wyborczego.

\section{Kwoty płci na listach wyborczych}

Kodeks wyborczy z 2011 roku gwarantuje kobietom i mężczyznom 35\% miejsc na listach wyborczych. Toczą się jednak prace legislacyjne nad modyfikacją tego mechanizmu, wskazuje się bowiem, że jest on w obecnej formie nieskuteczny. Na podstawie naszego badania należy uznać, że przyjęte w Kodeksie wyborczym rozwiązanie zadowala stosunkowo niewielką część społeczeństwa, choć bez wątpienia można je uznać za rozstrzygnięcie kompromisowe, uwzględniające przeciwstawne racje i poglądy. Opinie Polaków na temat mechanizmów wyrównywania udziału kandydatów obu płci w instytucjach przedstawicielskich są podzielone. $\mathrm{Z}$ jednej strony niemal połowa badanych (48\%) jest zdania, że prawo w ogóle nie powinno określać odsetka kobiet na listach wyborczych, z drugiej zaś zwolennicy prawnych gwarancji równości płci (łącznie 45\%) zdecydowanie częściej opowiadają się za parytetem na listach wyborczych (36\%) niż za udziałem kobiet ograniczonym do poziomu 35 procent (9\%). Mniej ważne niż określenie kwotowego udziału kandydatów obu płci na listach wyborczych jest - w ocenie społecznej - umieszczenie na tych listach naprzemiennie nazwisk kandydatów - kobiet i mężczyzn - na zasadzie tzw. suwaka. 
Rysunek 1. Jaki powinien być, Pana(i) zdaniem, gwarantowany przez prawo udział kobiet na listach wyborczych do Parlamentu Europejskiego? Które z poniższych rozwiązań bardziej się Panu(i) podoba?
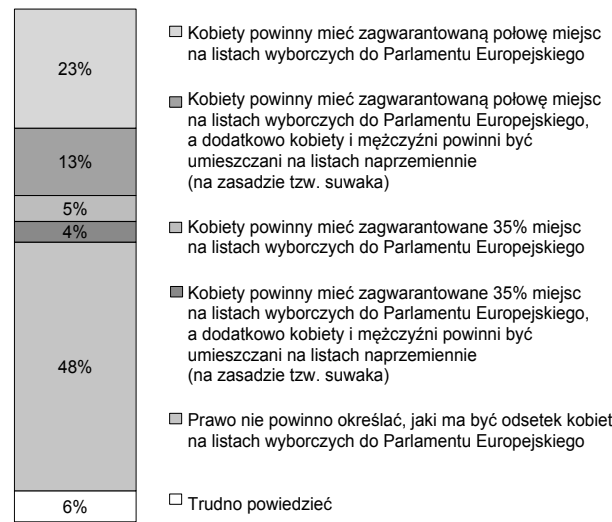

$\square$ Trudno powiedzieć

Podobne pytanie zadaliśmy naszym respondentom we wrześniu 2011 roku, ${ }^{3}$ przed zbliżającymi się wyborami do Sejmu i Senatu. Wówczas $26 \%$ badanych opowiedziało się za gwarantowanym prawnie parytetem płci na listach wyborczych do Sejmu, 13\% - za co najmniej 35-procentowym udziałem kobiet i mężczyzn na listach wyborczych. Ponad połowa respondentów (51\%) była przeciwna określaniu przez prawo odsetka kandydatów określonej płci na listach wyborczych. Oznacza to, że w ciągu ostatnich lat nieco przybyło zwolenników wyrównania proporcji kandydatów obu płci w wyborach.

Opinie na temat wyrównywania liczby kobiet i mężczyzn na listach wyborczych różnicuje płeć. Generalnie, rozwiązania zmierzające w kierunku promowania równości płci częściej popierają kobiety (ogółem 51\%) niż mężczyźni (39\%). Co ciekawe, ich stosunek do zwiększania udziału kobiet na listach wyborczych zależy od sytuacji materialnej (dochodów per capita w gospodarstwie domowym), a także - w mniejszym stopniu - od wykształcenia. Potrzebę zapewnienia mechanizmów prawnych gwarantujących kobietom określoną pulę miejsc na listach wyborczych dostrzegają przede wszystkim kobiety gorzej sytuowanie i słabiej wykształcone. Podobne, choć słabsze zależności obserwujemy w przypadku mężczyzn. Dodatkowo w grupie mężczyzn opinie w tej kwestii różnicuje wiek. Najwięcej zwolenników wyrównywania szans kobiet w polityce poprzez kwoty płci na listach wyborczych jest wśród najstarszych respondentów (powyżej 65 lat, ogółem 51\%), najmniej wśród młodych mężczyzn w wieku od 18 do 24 lat (30\%, przy 69\% przeciwników). Opinii

3 B. Roguska, J. Zbieranek, Wiedza i opinie Polaków o prawie wyborczym i mechanizmach kampanii, Warszawa 2011. 
w tej kwestii nie różnicują znacząco ani deklarowane poglądy polityczne (określane na skali lewica-prawica), ani religijność badanych, niezależnie od ich płci.

Społeczne poparcie dla rozwiązań prawnych mających na celu wspieranie kobiet w polityce nie jest zatem kwestią formacji światopoglądowej, ale może wynikać $\mathrm{z}$ resentymentu grup słabszych ekonomicznie i społecznie.

Tabela 1. Opinie kobiet na temat kwot płci na listach wyborczych

\begin{tabular}{|c|c|c|c|c|}
\hline \multirow{3}{*}{$\begin{array}{l}\text { Miesięczne do- } \\
\text { chody per capita } \\
\text { w gospodarstwie } \\
\text { domowym }\end{array}$} & \multicolumn{4}{|c|}{$\begin{array}{l}\text { Jaki powinien być, Pani zdaniem, gwarantowany przez prawo udział kobiet na listach wybor- } \\
\text { czych do Parlamentu Europejskiego? Które z poniższych rozwiązań bardziej się Pani podoba? }\end{array}$} \\
\hline & $\begin{array}{c}\text { Kobiety powinny mieć za- } \\
\text { gwarantowaną połowę miejsc } \\
\text { na listach wyborczych do } \\
\text { Parlamentu Europejskiego } \\
\text { (ew. dodatkowo kobiety } \\
\text { i mężczyźni powinni być } \\
\text { umieszczani na listach na- } \\
\text { przemiennie, na zasadzie tzw. } \\
\text { suwaka) }\end{array}$ & $\begin{array}{c}\text { Kobiety powinny mieć za- } \\
\text { gwarantowane } 35 \% \text { miejsc } \\
\text { na listach wyborczych do } \\
\text { Parlamentu Europejskiego } \\
\text { (ew. dodatkowo kobiety } \\
\text { i mężczyźni powinni być } \\
\text { umieszczani na listach na- } \\
\text { przemiennie, na zasadzie tzw. } \\
\text { suwaka) }\end{array}$ & $\begin{array}{c}\text { Prawo nie po- } \\
\text { winno określać, } \\
\text { jaki ma być odse- } \\
\text { tek kobiet na li- } \\
\text { stach wyborczych } \\
\text { do Parlamentu } \\
\text { Europejskiego }\end{array}$ & $\begin{array}{l}\text { Trudno } \\
\text { powiedzieć }\end{array}$ \\
\hline & \multicolumn{4}{|c|}{ w procentach } \\
\hline Do $500 \mathrm{zł}$ & 54 & 10 & 27 & 9 \\
\hline $501-750$ & 44 & 4 & 44 & 7 \\
\hline $751-1000$ & 39 & 12 & 40 & 9 \\
\hline $1001-1500$ & 33 & 14 & 50 & 3 \\
\hline Powyżej 1500 zł & 28 & 16 & 51 & 5 \\
\hline
\end{tabular}

Tabela 2. Opinie kobiet na temat kwot płci na listach wyborczych

\begin{tabular}{|c|c|c|c|c|}
\hline \multirow{3}{*}{ Wykształcenie } & \multicolumn{4}{|c|}{$\begin{array}{l}\text { Jaki powinien być, Pani zdaniem, gwarantowany przez prawo udział kobiet na listach wy- } \\
\text { borczych do Parlamentu Europejskiego? Które z poniższych rozwiązań bardziej się Pani } \\
\text { podoba? }\end{array}$} \\
\hline & $\begin{array}{c}\text { Kobiety powinny mieć za- } \\
\text { gwarantowaną połowę } \\
\text { miejsc na listach wybor- } \\
\text { czych do Parlamentu Euro- } \\
\text { pejskiego (ew. dodatkowo } \\
\text { kobiety i mężczyźni powinni } \\
\text { być umieszczani na listach } \\
\text { naprzemiennie, na zasadzie } \\
\text { tzw. suwaka) }\end{array}$ & $\begin{array}{c}\text { Kobiety powinny mieć za- } \\
\text { gwarantowane } 35 \% \text { miejsc } \\
\text { na listach wyborczych do } \\
\text { Parlamentu Europejskiego } \\
\text { (ew. dodatkowo kobiety } \\
\text { i mężczyźni powinni być } \\
\text { umieszczani na listach na- } \\
\text { przemiennie, na zasadzie } \\
\text { tzw. suwaka) }\end{array}$ & $\begin{array}{c}\text { Prawo nie po- } \\
\text { winno określać, } \\
\text { jaki ma być odse- } \\
\text { tek kobiet na li- } \\
\text { stach wyborczych } \\
\text { do Parlamentu } \\
\text { Europejskiego }\end{array}$ & $\begin{array}{c}\text { Trudno } \\
\text { powiedzieć }\end{array}$ \\
\hline & \multicolumn{4}{|c|}{ w procentach } \\
\hline $\begin{array}{l}\text { Podstawowe/ } \\
\text { gimnazjalne }\end{array}$ & 39 & 16 & 30 & 15 \\
\hline $\begin{array}{l}\text { Zasadnicze } \\
\text { zawodowe }\end{array}$ & 49 & 8 & 37 & 6 \\
\hline Średnie & 42 & 7 & 43 & 7 \\
\hline Wyższe & 32 & 12 & 54 & 2 \\
\hline
\end{tabular}




\section{Polacy o procedurach głosowania}

Od blisko dwudziestu lat prowadzone są w Polsce prace nad wprowadzaniem do prawa wyborczego tzw. alternatywnych procedur głosowania, umożliwiających oddawanie głosu poza lokalem wyborczym. ${ }^{4}$ Ustawodawca zdecydował się w pierwszej kolejności adresować je do grup wyborców napotykających największe trudności w głosowaniu. Od roku 2010 osoby niepełnosprawne oraz w zaawansowanym wieku mogą korzystać z procedury głosowania przez pełnomocnika, ponadto od 2011 roku wyborcy niepełnosprawni oraz przebywający poza granicami kraju mogą oddawać głos korespondencyjnie. W chwili przeprowadzania badania trwały prace koncepcyjne i legislacyjne nad wprowadzeniem kolejnych procedur (głosowanie przez Internet) oraz nad umożliwieniem korzystania z procedur już wprowadzonych wszystkim wyborcom (głosowanie korespondencyjne). ${ }^{5}$

Reforma procedur głosowania nie jest procesem o charakterze wyłącznie organizacyjnym czy technicznym, ale również społecznym - $i$ towarzyszyć jej powinny regularne badania opinii społecznej, wskazujące na różne aspekty zmian, w tym kwestie zaufania do procedur. Zgodnie z dotychczasowymi ustaleniami z wcześniejszego, marcowego badania przeprowadzonego przez CBOS oraz Biuro Rzecznika Praw Obywatelskich, ${ }^{6}$ Polacy są generalnie zwolennikami wprowadzenia do polskiego prawa wyborczego alternatywnych procedur głosowania, ale uważają, że powinny być one adresowane głównie do wyborców napotykających na trudności w dotarciu do lokalu wyborczego.

Rysunek 2. O każdej z przedstawionych form głosowania proszę powiedzieć, czy powinna być taka możliwość czy też nie?

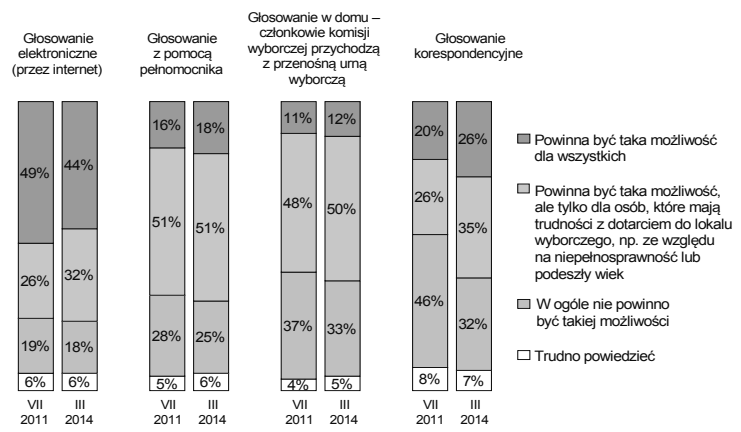

Źródło: B. Roguska, J. Zbieranek, Ułatwienia w głosowaniu-wiedza, opinie i oczekiwania, Warszawa 2014.

4 Więcej: J. Zbieranek, Alternatywne procedury głosowania w polskim prawie wyborczym - gwarancja zasady powszechności wyborów czy mechanizm zwiększania frekwencji wyborczej?, Warszawa 2013.

$5 \quad$ Zakończone przygotowaniem takiej zmiany i wprowadzeniem do ustawy z dnia 5 stycznia 2011 roku Kodeks wyborczy procedury głosowania korespondencyjnego dostępnej dla wszystkich wyborców.

6 B. Roguska, J. Zbieranek, Ułatwienia w głosowaniu - wiedza, opinie i oczekiwania, Warszawa 2014. Badanie „Aktualne problemy i wydarzenia” (286) przeprowadzono metodą wywiadów bezpośrednich (face-to-face) wspomaganych komputerowo (CAPI) w dniach 6-12 marca 2014 roku na liczącej 1098 osób reprezentatywnej próbie losowej dorosłych mieszkańców Polski. 
Pytani o własne preferencje, badani w większości (ponad dwie trzecie) wskazują, że chcieliby głosować w lokalu wyborczym. Tylko jedna trzecia ankietowanych wskazuje inne procedury, ale warto podkreślić, że grupa ta rośnie.

Rysunek 3. Gdyby miał(a) Pan(i) wybór, jak głosować, to wolał(a)by Pan(i) głosować:

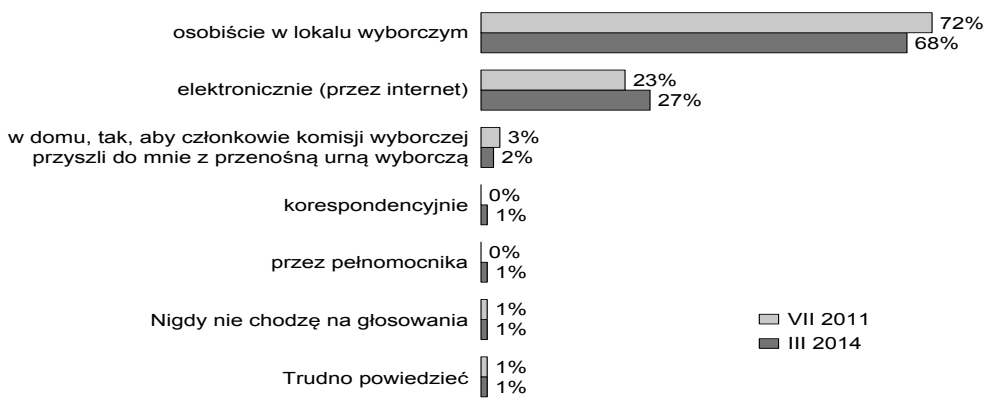

Źródto: B. Roguska, J. Zbieranek, Utatwienia w głosowaniu-wiedza, opinie i oczekiwania, Warszawa 2014.

W kwietniowym (2014 rok) badaniu zapytaliśmy Polaków o ich zaufanie do poszczególnych, istniejących bądź dopiero proponowanych, procedur głosowania. Bezpieczeństwo i uczciwość procedur są niezmiernie istotne, a kwestie te są często poruszane w debacie publicznej, warto więc przybliżyć opinie samych wyborców na ten temat.

Rysunek 4. Trwają prace nad zmianami procedur oddawania głosu. Obok tradycyjnego głosowania w lokalu wyborczym proponowane są inne sposoby głosowania. Czy widzi Pan(i) zagrożenie nadużyć, czy nawet fałszerstw wyborczych w przypadku*:

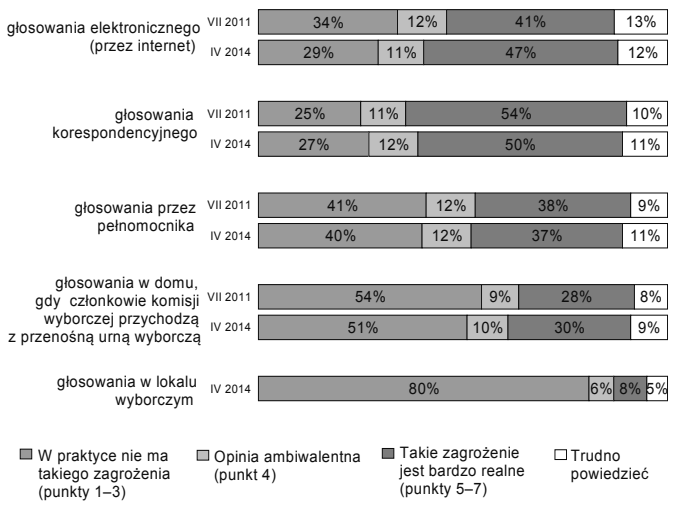

Badani zaznaczali odpowiedzi na 7-punktowej skali

* W roku 2011 pytanie brzmiato: „,Mówi się czasem o niebezpieczeństwie nadużyć, a nawet fatszerstw wyborczych związanych z możliwościa glosowania inaczej niż w lokalu wyborczym. Czy widzi Pan(i) tego rodzaju zagrożenie w przypadku:" 
Przede wszystkim Polacy zapytani zostali o tradycyjną procedurę głosowania w lokalu wyborczym. Zdecydowana większość ankietowanych (80\%) stwierdziła, że nie widzi zagrożeń i niebezpieczeństwa nadużyć, natomiast $8 \%$ uznało, że są one realne. Bardziej zróżnicowane opinie Polacy prezentują wobec alternatywnych procedur głosowania.

Najmniej wątpliwości w kwestii bezpieczeństwa głosowania budziło głosowanie z wykorzystaniem mobilnej urny wyborczej, z którą członkowie komisji wyborczej przybywają do domu wyborcy. Ponad połowa badanych (51\%) uznała, że nie wiąże się to z żadnym zagrożeniem. Nieco więcej wątpliwości budzi procedura głosowania przez pełnomocnika - w tym przypadku zdania ankietowanych są podzielone. Przy dwóch kolejnych procedurach oceny ankietowanych opinie wskazujące na zagrożenia przeważają. W odniesieniu do procedury głosowania przez Internet poważne wątpliwości ma blisko $47 \%$ badanych, podczas gdy mniejszość $(29 \%)$ wskazuje na brak takiego zagrożenia. Natomiast oceniając procedurę głosowania korespondencyjnego, połowa badanych (50\%) wskazuje na niebezpieczeństwo nadużyć, natomiast $28 \%$ nie podziela tych obaw.

Warto podkreślić, że powyższe wyniki w porównaniu z analogicznym badaniem przeprowadzonym w $2011 \mathrm{roku}^{7}$ są niemal takie same. Podkreślenia wymaga też wysoka ocena tradycyjnej procedury głosowania w lokalu wyborczym, co świadczy o dużym zaufaniu do organów wyborczych. Natomiast im bardziej procedury alternatywne przewidują mniejszą bezpośrednią ich kontrolę, tym większe budzą wątpliwości. O ile głosowanie wykorzystujące mobilną urnę wyborczą i głosowanie przez pełnomocnika mogą być postrzegane jako procedury z relatywnie dużym, bezpośrednim zaangażowaniem organów wyborczych czy, szerzej, instytucji publicznych, to procedury zdalne - głosowanie korespondencyjne i elektroniczne (przez Internet) - postrzegane są w tym kontekście jako objęte, ze względu na ich specyfikę, mniejszą kontrolą.

Kwestią o ogromnym znaczeniu dla skutecznego funkcjonowania alternatywnych procedur głosowania jest poinformowanie o nich wyborców, a w szczególności ich adresatów. Obok powyżej przedstawionych badań opinii społecznej realizowanych w kwietniu 2014 roku przez Centrum Studiów Wyborczych i CBOS, w niniejszym artykule postanowiliśmy zaprezentować najnowsze wyniki obejmujące okres bezpośrednio przed wyborami Prezydenta RP (kwiecień 2015 roku) pochodzące $\mathrm{z}$ badania będącego wspólną inicjatywą Centrum Badania Opinii Społecznej i Biura Rzecznika Praw Obywatelskich. ${ }^{8}$ Miało ono na celu przedstawienie stanu wiedzy Polaków na temat głosowania korespondencyjnego i przez pełnomocnika. Warto pod-

7 B. Roguska, J. Zbieranek, Polacy o ułatwieniach w głosowaniu, Warszawa 2011.

8 Badanie „Aktualne problemy i wydarzenia” (299) przeprowadzono metodą wywiadów bezpośrednich (face-to-face) wspomaganych komputerowo (CAPI) w dniach 16-22 kwietnia 2015 roku na liczącej 1027 osób reprezentatywnej próbie losowej dorosłych mieszkańców Polski. Badanie zostało przedstawione w komunikacie: J. Zbieranek, Wiedza o ułatwieniach w głosowaniu przed wyborami prezydenckimi, Warszawa 2015. 
kreślić, że wspomniane badanie zostało przeprowadzone w ostatnich dniach przed upływem ostatecznego terminu zgłaszania zamiaru skorzystania $\mathrm{z}$ tych ułatwień.

Jak już zostało podkreślone, procedurę głosowania korespondencyjnego do polskiego prawa wprowadzono w 2011 roku z myślą o dwóch grupach wyborców, którzy mieli szczególnie duże problemy z dotarciem do lokali wyborczych. Uprawnionymi do jej stosowania zostali bowiem wyborcy niepełnosprawni i Polacy przebywający poza granicami kraju. Procedurę tę po raz pierwszy zastosowano w wyborach parlamentarnych w 2011 roku, kiedy to zamiar skorzystania z niej skutecznie wyraziło blisko 23000 wyborców (przede wszystkim przebywających poza granicami kraju, a w znacznie mniejszym zakresie - wyborców niepełnosprawnych w kraju). Uznano to za sukces, biorąc pod uwagę ówczesny ogromny poziom nieznajomości nowej procedury wśród Polaków. Jak wynikało bowiem z badań CBOS przeprowadzonych w 2011 roku, ${ }^{9}$ na kilka tygodni przed wyborami parlamentarnymi, dla większości badanych, w tym dla przeważającej większości osób niepełnosprawnych, nowa procedura pozostawała zupełnie nieznana.

W roku 2014 w toku prac legislacyjnych nad nowelizacją Kodeksu wyborczego zdecydowano, że głosowanie korespondencyjne będzie procedurą, z której skorzystać będą mogli wszyscy Polacy. Ustalono przy tym, że po raz pierwszy tak szerokie zastosowanie głosowanie korespondencyjne będzie miało w wyborach na urząd Prezydenta RP w 2015 roku. Eksperci, organizacje społeczne oraz Rzecznik Praw Obywatelskich wskazywali wówczas (i apelowali, m.in. do Państwowej Komisji Wyborczej), że należy wykorzystać nadchodzące kilka miesięcy na kompleksową, dobrze przemyślaną akcję informacyjną mającą upowszechnić wiedzę o korespondencyjnej metodzie głosowania i osobach uprawnionych do jej stosowania.

Niestety, z badania przeprowadzonego w kwietniu 2015 roku, na kilka (!) dni przed upływem terminu zgłaszania zamiaru skorzystania z procedury wynika, że tylko 15\% Polaków miało świadomość, iż każdy wyborca może zagłosować korespondencyjnie. Aż $60 \%$ badanych nie wiedziało o tej możliwości nic, natomiast pozostali wskazali błędne odpowiedzi. O tym, że uprawnieni do skorzystania z tej procedury są tylko wyborcy niepełnosprawni i przebywający poza granicami kraju, przekonanych jest $14 \%$ badanych. Na marynarzy i żołnierzy wskazało $8 \%$, a o wyłącznym uprawnieniu osób w wieku powyżej 75 . roku życia przekonanych jest $2 \%$ ankietowanych.

Warto zauważyć, iż nieco większą wiedzę na temat grupy uprawnionych do głosowania korespondencyjnego mają wyborcy najmłodsi (w wieku 18-24 lata) - o tym, że każdy wyborca może skorzystać z tej procedury wie blisko co czwarty badany z tej grupy. Małą wiedzą charakteryzuje się natomiast grupa starszych bada-

9 Zob. komunikat z badań CBOS „Polacy o ułatwieniach w głosowaniu”, lipiec 2011 (oprac. B. Roguska, J. Zbieranek). 
nych (powyżej 65. roku życia), spośród których jedynie co dziesiąty wskazał właściwą odpowiedź.

Rysunek 5. Kto, zgodnie z przepisami, może głosować korespondencyjnie?

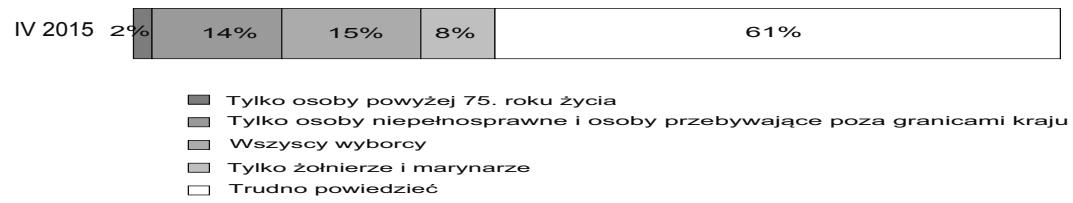

Źródło: J. Zbieranek, Wiedza o ułatwieniach w głosowaniu przed wyborami prezydenckimi, Warszawa 2015.

W tym kontekście nie mogą dziwić bardzo rzadkie deklaracje skorzystania z tej procedury. Na zamiar głosowania korespondencyjnego wskazało bowiem niespełna $3 \%$ ankietowanych, niezdecydowanych było $6 \%$, a $92 \%$ ankietowanych nie zamierzało z niego skorzystać.

Wyborcy niepełnosprawni i w zaawansowanym wieku (powyżej 75 lat) mogą skorzystać z innej procedury - głosowania przez pełnomocnika. Jest ona stosowana w tej samej formule już od 2010 roku. Cykliczne badania prowadzone w latach 2011 (przed wyborami parlamentarnymi) i 2014 (przed wyborami do Parlamentu Europejskiego i samorządowymi) wskazywały, że nie była ona szerzej znana Polakom. Również w kwietniu 2015 roku pełną wiedzę, kto jest do niej uprawniony miało tylko $22 \%$ ogółu ankietowanych. Co piąty wskazywał na odpowiedzi częściowo poprawne. Większość badanych (54\%) nie ma o procedurze żadnej wiedzy. Poziom poinformowania Polaków jest więc bardzo podobny jak w ubiegłych latach.

Rysunek 6. Czy orientuje się Pan(i), kto, zgodnie z obecnymi przepisami prawa wyborczego, może głosować przez pełnomocnika?

\begin{tabular}{|c|c|c|c|c|c|}
\hline $1 \times 2011$ & $3 \%$ & $18 \%$ & $23 \%$ & $1 \%$ & $55 \%$ \\
\hline III 2014 & $3 \%$ & $18 \%$ & $23 \%$ & $2 \%$ & $54 \%$ \\
\hline IV 2015 & $3 \%$ & $19 \%$ & $22 \%$ & $2 \%$ & $54 \%$ \\
\hline
\end{tabular}

Źródto: J. Zbieranek, Wiedza o ułatwieniach w głosowaniu przed wyborami prezydenckimi, Warszawa 2015.

Niestety, co bardzo niepokojące, wśród adresatów procedury głosowania przez pełnomocnika wiedza również nie jest duża. O takiej możliwość wie jedynie co piąty 
ankietowany w wieku powyżej 75. roku życia. Blisko 80\% starszych wyborców nie wie nic o tej procedurze lub błędnie wskazuje uprawnionych.

Rysunek 7. Czy orientuje się Pan(i), kto, zgodnie z obecnymi przepisami prawa wyborczego, może głosować przez pełnomocnika?

(odpowiedzi osób w wieku 75 i więcej lat)

IV 2015

\begin{tabular}{|l|l|l|l|}
\hline $6 \%$ & $17 \%$ & $15 \%$ & $61 \%$ \\
\hline
\end{tabular}

Tylko osoby powyżej 75. roku życia

$\square$ Tylko osoby niepełnosprawne

$\square$ Osoby niepełnosprá

Źródło: J. Zbieranek, Wiedza o ułatwieniach w głosowaniu przed wyborami prezydenckimi, Warszawa 2015.

Lepiej poinformowani są wyborcy posiadający właściwe orzeczenie o niepełnosprawności, choć i w tej grupie wciąż większość badanych nie ma żadnej wiedzy o procedurze głosowania przez pełnomocnika lub błędnie określa uprawnionych do korzystania z niej.

\section{Opinie o obniżeniu wieku wyborczego do 16 lat}

Od kilku lat w debacie publicznej formułowane są propozycje, aby umożliwić obywatelom głosowanie w wyborach już po ukończeniu 16 lat. Zwolennicy obniżenia wieku wyborczego wskazują, że taka zmiana przyczyni się do lepszej reprezentacji ludzi młodych i może zwiększyć aktywność młodzieży. Trwają prace koncepcyjne nad tą propozycją, przygotowano również projekt ustawy, przewidujący wprowadzenie takiej zmiany w wyborach do Parlamentu Europejskiego. ${ }^{10}$

W badaniu przeprowadzonym w marcu 2014 roku $^{11}$ zapytaliśmy Polaków o ich zdanie na temat propozycji obniżenia wieku wyborczego do 16 lat. Wynika z niego, że większość badanych (84\%) jest przeciwna tej zmianie. Co warte podkreślenie, zdecydowanie przeciwnych jest aż $60 \%$ badanych. Zwolennikami głosowania 16-latków jest niespełna 12\% badanych.

\footnotetext{
10 Więcej na temat proponowanych zmian i ewolucji procedury wyborczej w wyborach do Parlamentu Europejskiego: K.F. Oelbermann, F. Pukelsheim, Future European Parliament Elections: Ten Steps Towards Uniform Procedures, „Zeitschrift fur Staats und Europawissenschaften”, 2011, n. 1, s. 9-28, M. Rulka, J. Zbieranek, W kierunku jednolitego aktu? System prawa wyborczego do Parlamentu Europejskiego, (w:) W stronę europejskiego demos? Polskie wybory do Parlamentu Europejskiego w 2009 roku w perspektywie porównawczej, J. Kucharczyk, A. Łada (red.), Warszawa 2010, Drugie sprawozdanie w sprawie wniosku dotyczącego zmiany Aktu dotyczącego wyborów przedstawicieli do Parlamentu Europejskiego w powszechnych wyborach bezpośrednich z dnia 20 września 1976 r. (2009/2134(INI).

11 J. Zbieranek (red.), Europejskie wybory młodych, Toruń 2014.
} 
Rysunek 8. Toczą się dyskusje nad obniżeniem wieku wyborczego. Co Pan(i) sądzi o propozycji, aby prawo głosowania przysługiwało osobom, które ukończyły 16. rok życia, a nie tak jak obecnie, po ukończeniu 18 lat?

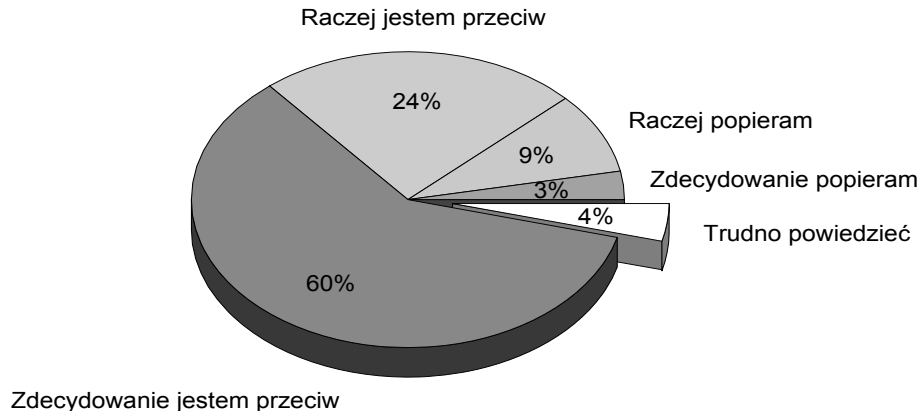

Warto zwrócić uwagę, że negatywnie propozycję obniżenia wieku do 16 lat oceniają najmłodsi badani, którzy jeszcze niedawno sami byli w tym wieku. Przeciwko takiemu rozwiązaniu jest $82 \%$ ankietowanych w wieku 18-24 lata, popiera je natomiast $15 \%$ z nich.

\section{Opinie o mechanizmach kampanii wyborczych}

\section{a) Cisza wyborcza}

Kodeks wyborczy przewiduje, że na 24 godziny przed dniem wyborów i aż do zakończenia głosowania zakazane jest prowadzenie agitacji wyborczej, a także publikowanie wyborczych sondaży. Czas ten, nazywany powszechnie ciszą wyborczą, ma m.in. obniżyć poziom emocji i umożliwić wyborcy spokojny, niezakłócony namysł w okresie bezpośrednio poprzedzającym oddanie przez niego głosu. Od kilku lat pojawiają się jednak istotne argumenty na rzecz zlikwidowania tej instytucji, jako nikomu niepotrzebnego anachronizmu, który wraz z dynamicznym rozwojem kanałów komunikacji internetowej całkowicie stracił rację bytu. Postanowiliśmy sprawdzić, co o instytucji ciszy wyborczej sądzą Polacy.

Zdecydowana większość badanych (72\% ankietowanych) uważa, że cisza wyborcza jest potrzebna, $60 \%$ wskazuje, że powinna być zachowana w obecnym kształcie, 7\% sądzi, że powinna być skrócona, natomiast 5\% - że wręcz wydłużona. Co ważne, opinie o ciszy wyborczej są podobne w poszczególnych grupach wiekowych - w tym wśród osób młodych. Zdecydowanymi przeciwnikami ciszy wyborczej jest niespełna $18 \%$ badanych. 
Rysunek 9. 24 godziny przed dniem wyborów, aż do zakończenia głosowania obowiązuje tzw. cisza wyborcza, w czasie której nie można prowadzić m.in. agitacji wyborczej czy podawać wyników sondaży. Co Pan(i) sądzi o ciszy wyborczej?

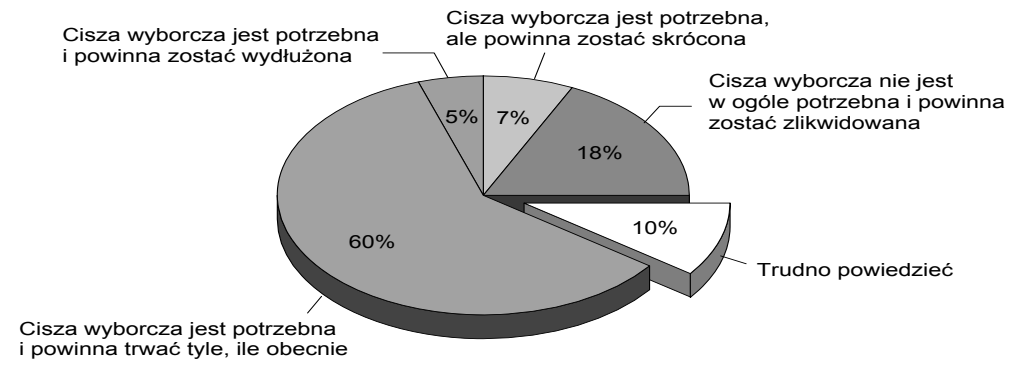

\section{b) Źródła wiedzy o wyborach}

W dalszej części badania zwróciliśmy uwagę na zagadnienie przekazywania informacji na tematy związane z wyborami. Najczęstszym źródłem informacji o kandydatach w wyborach do Parlamentu Europejskiego jest telewizja. Na telewizyjne programy informacyjne i publicystyczne jako jedno z głównych źródeł wiedzy o wyborach wskazało ponad dwie piąte badanych (42\%). Niemal tyle samo osób (40\%) wymieniło w tym kontekście spoty i reklamy wyborcze. Porównywalnymi pod względem popularności kanałami pozyskiwania informacji o wyborach i kandydatach do Parlamentu Europejskiego są Internet i prasa (odpowiednio 31\% i 29\% wskazań). Mniej znacząca jest rola radia - radiowe audycje informacyjne i publicystyczne do najważniejszych źródeł wiedzy o wyborach zaliczyło 19\% badanych. Jeszcze mniej osób zadeklarowało, że czerpie informacje o wyborach przede wszystkim z billboardów, plakatów wyborczych oraz z rozmów ze znajomymi i rodziną (po $11 \%$ ). Jedynie bardzo nieliczne osoby (1\%) korzystają z takich sposobów pozyskiwania informacji o kandydatach jak wiece i spotkania wyborcze.

Rysunek 10. Skąd przede wszystkim czerpie Pan(i) informacje na temat kandydatek i kandydatów w wyborach do Parlamentu Europejskiego? Proszę wskazać nie więcej niż trzy źródła informacji z podanej listy.

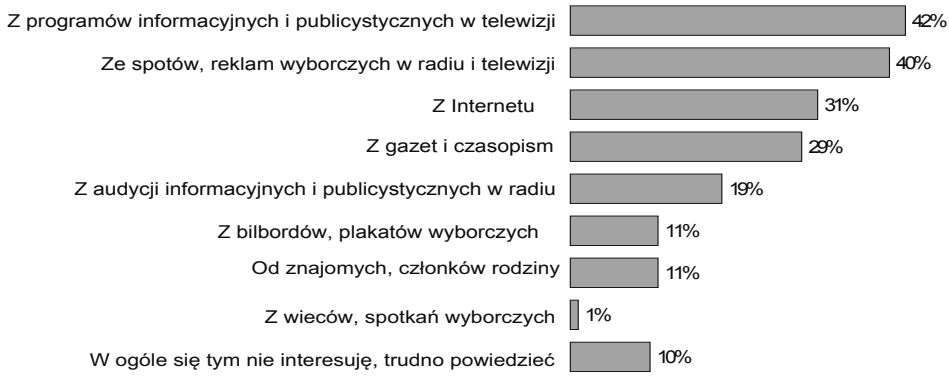


Korzystanie z Internetu jest najbardziej zróżnicowane w zależności od cech społeczno-demograficznych respondentów. Dla młodych ludzi, mających od 18 do 24 lat, stanowi on najważniejsze źródło wiedzy o wyborach i kandydatach do Parlamentu Europejskiego, zastępując w jakiejś mierze tradycyjne media - na Internet wskazało aż $60 \%$ badanych $\mathrm{z}$ tej grupy wiekowej, a na telewizyjne programy informacyjne i publicystyczne - tylko $28 \%$. Także wśród nieco starszych respondentów, mających od 25 do 34 lat, Internet uzyskał najwięcej wskazań jako źródło wiedzy o wyborach (50\%). Wraz z wiekiem maleje znaczenie Internetu w pozyskiwaniu informacji o wyborach - w najstarszej grupie (65 lat i więcej) wymieniło go $7 \%$ ankietowanych.

Korzystanie z Internetu wiąże się także z wykształceniem. Wśród głównych źródeł informacji o wyborach wskazało go $50 \%$ badanych z wyższym wykształceniem i $18 \%$ mających wykształcenie podstawowe.

\section{c) Opinie dotyczące spotów wyborczych}

Jak pokazują wyniki badania, spoty wyborcze należą do najczęściej wymienianych źródeł wiedzy o wyborach. Są one wykorzystywane nie tylko do promowania własnego ugrupowania, ale nierzadko także do dyskredytowania politycznych przeciwników. Przykładów takiego czarnego PR dostarczyła także kampania w 2014 r. przed wyborami europejskimi. Pojawiają się postulaty, także w toku prac legislacyjnych nad nowelizacją kodeksu wyborczego, by ustawowo zakazać dyskredytowania innych kandydatów nie tylko w nieodpłatnych, ale także w odpłatnych audycjach wyborczych, emitowanych przez nadawców radiowych i telewizyjnych. Badania pokazują, że taki zakaz podobałby się Polakom. W opinii niemal połowy badanych (46\%) spoty radiowe i telewizyjne są potrzebne, ale powinno się zabronić dyskredytowania w nich innych kandydatów. Niemal co trzeci ankietowany uważa, że taka forma prowadzenia kampanii wyborczej jest w ogóle niepotrzebna. Tylko 13\% jest zdania, że spoty wyborcze są potrzebne i dobrze wykorzystywane przez komitety wyborcze.

Rysunek 11. W wyborach do Parlamentu Europejskiego ugrupowania prowadzą kampanię między innymi za pomocą spotów telewizyjnych i radiowych.

Czy uważa Pan(i), że spoty telewizyjne i radiowe:
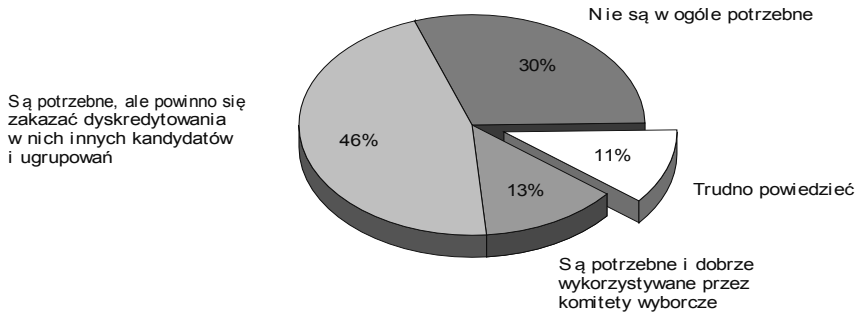


\section{Podsumowanie}

Badanie pozwala na sformułowanie kilku wniosków, które mogą być przydatne w toku dalszych prac koncepcyjnych i legislacyjnych nad zmianami prawa wyborczego. Bardzo jednoznacznie Polacy wypowiadają się przeciwko propozycji umożliwienia głosowania już od ukończenia 16. roku życia. Zdecydowana większość badanych chciałaby zachowania instytucji ciszy wyborczej.

Polacy ogromnym zaufaniem darzą procedurę głosowania w lokalu wyborczym, lecz wyrażają wiele wątpliwości dotyczących bezpieczeństwa procedur zdalnych - głosowania korespondencyjnego oraz elektronicznego (z wykorzystaniem Internetu).

Wyniki badań przedstawiające wiedzę wyborców o obecnie funkcjonujących w polskim prawie wyborczym alternatywnych procedurach głosowania mogą budzić poważne zaniepokojenie. Zdecydowana większość badanych nic nie wie o procedurze głosowania korespondencyjnego. Nieco lepiej Polacy są zorientowani w kwestii głosowania przez pełnomocnika (stosowanego już w kilku wyborach). Co jednak najbardziej niepokojące, relatywnie niewielką wiedzę o tych procedurach mają wyborcy, którzy mogą ich szczególnie potrzebować. Tylko niespełna co piąty wyborca niepełnosprawny wie o tym, że może głosować korespondencyjnie. Podobnie - co piąty starszy wyborca jest świadomy, że może oddać głos przez pełnomocnika.

Wracając do opinii Polaków, kontrowersje budzi system kwot płci na listach wyborczych. $Z$ pewnością obecne rozwiązanie satysfakcjonuje nieliczną grupę badanych. $Z$ jednej strony nadal blisko połowa badanych uważa, że prawo nie powinno określać odsetka kobiet i mężczyzn na listach wyborczych. $Z$ drugiej strony dwie piąte respondentów postuluje rozwiązanie dalej idące - w postaci parytetu, mniejsza zaś grupa - tzw. system suwakowy.

\section{BIBLIOGRAFIA}

Komunikat z badań CBOS „Polacy o ułatwieniach w głosowaniu”, lipiec 2011 (oprac. B. Roguska, J. Zbieranek)

Oelbermann K.F., Pukelsheim F., Future European Parliament Elections: Ten Steps Towards Uniform Procedures, „Zeitschrift fur Staats und Europawissenschaften”, 2011, nr 1

Roguska B., Zbieranek J., Polacy o ułatwieniach w głosowaniu, Warszawa 2011

Roguska B., Zbieranek J., Wiedza i opinie Polaków o prawie wyborczym i mechanizmach kampanii, Warszawa 2011

Roguska B., J. Zbieranek, Ułatwienia w głosowaniu - wiedza, opinie i oczekiwania, Warszawa 2014

Rulka M., Zbieranek J., W kierunku jednolitego aktu? System prawa wyborczego do Parlamentu Europejskiego (w:) J. Kucharczyk, A. Łada (red.), W stronę europejskiego demos? Polskie wybory do Parlamentu Europejskiego w 2009 roku w perspektywie porównawczej, Warszawa 2010

Zbieranek J., (red.), Europejskie wybory młodych, Toruń 2014 
Opinie Polaków o propozycjach zmian w prawie wyborczym

Zbieranek J., Alternatywne procedury głosowania w polskim prawie wyborczym - gwarancja zasady powszechności wyborów czy mechanizm zwiększania frekwencji wyborczej?, Warszawa 2013

Zbieranek J., Wiedza o ułatwieniach w głosowaniu przed wyborami prezydenckimi, Warszawa 2015 
OPINIONS OF POLES ABOUT POSTULATED CHANGES IN ELECTORAL LAW

After many years of effort, in 2011, a large package of new solutions was introduced to the Polish electoral law (postal-voting, quotas, etc.). But the process of changing electoral law cannot be considered as complete. Some of the solutions implemented require adjustment and modification (such as electoral quotas). It is also worth taking into account, inter alia, demographic changes and technological developments; considering the prospects for the evolution of mechanisms in the long term (such as the introduction of electronic voting and reducing the voting age). A few weeks before the European Parliament elections in 2014, the Centre of Electoral Studies and the Public Opinion Research Center, conducted polls to assess public opinion on a group of constructions that were being considered by experts and in parliamentary works on electoral law. The research shows that Poles are against the proposed reduction in voting age (to 16 years) as well as against removal of the "electoral silence" period. Opinion on electoral quotas was divided. The research also showed that although Poles are open to new, remote methods of voting (e.g. postal voting), they still preferred the "classic way" of voting in polling stations which they regarded as being the most trustworthy.

Keywords: electoral law, elections, public opinion surveys

Słowa kluczowe: prawo wyborcze, wybory, badania opinii społecznej 